\title{
Effect of temperature on single- and mixed-strain fermentation of ruminant feeds
}

\author{
Seungmin $\mathrm{Woo}^{1 \#}$, Sooah $\mathrm{Kim}^{2 \#}$, Suji Ye ${ }^{3 \#}$, Soo Rin $\mathrm{Kim}^{3 \#}$, Jeongman Seol ${ }^{3}$, \\ Uyeh Daniel Dooyum ${ }^{1}$, Junhee Kim ${ }^{1}$, Dong Hyuck Hong ${ }^{1}$, Jong Nam Kim ${ }^{4 *}$ \\ and Yushin $\mathrm{Ha}^{1 *}$ \\ ${ }^{1}$ Department of Bio Industrial Machinery Engineering, Kyungpook National University, Daegu 41566, Korea \\ ${ }^{2}$ Department of Environment Science \& Biotechnology, Jeonju University, Jeonju 55069, Korea \\ ${ }^{3}$ School of Food Science and Biotechnology, Kyungpook National University, Daegu 41566, Korea \\ ${ }^{4}$ Department of Food Science and Nutrition, Dongseo University, Busan 47011, Korea
}

Received: Nov 20, 2019

Revised: Jan 20, 2020

Accepted: Jan 21, 2020

\#These authors contributed equally to this work.

${ }^{*}$ Corresponding author Jong Nam Kim

Department of Food Science and Nutrition, Dongseo University,

Busan 47011, Korea.

Tel: +82-51-320-4878

E-mail: yorker20@gdsu.dongseo.ac.kr

Yushin $\mathrm{Ha}$

Department of Bio Industrial Machinery Engineering, Kyungpook National

University, Daegu 41566, Korea.

Tel: +82-53-950-5792

E-mail: yushin72@knu.ac.kr

Copyright ( $\odot 2020$ Korean Society of Animal Sciences and Technology. This is an Open Access article distributed under the terms of the Creative Commons Attribution Non-Commercial License (http:// creativecommons.org/licenses/by$\mathrm{nc} / 4.0 /$ ) which permits unrestricted non-commercial use, distribution, and reproduction in any medium, provided the original work is properly cited.

ORCID

Seungmin Woo

https://orcid.org/0000-0001-9434-2455 Sooah Kim

https://orcid.org/0000-0002-9096-4879 Suji Ye

https://orcid.org/0000-0003-3793-5451

\section{Abstract}

Use of raw feedstuffs for livestock is limited by low digestibility. Recently, fermentation of feedstuffs has been highlighted as a new way to improve nutrient absorption through the production of organic acids using inoculated microorganisms, which can also play a probiotic role. However, standard procedures for feedstuff fermentation have not been clearly defined because the process is influenced by climatic variation, and an analytical standard for fermented feedstuffs is lacking. This study aimed to evaluate the microbiological and biochemical changes of feedstuffs during fermentation at temperatures corresponding to different seasons $\left(10^{\circ} \mathrm{C}, 20^{\circ} \mathrm{C}, 30^{\circ} \mathrm{C}\right.$, and $\left.40^{\circ} \mathrm{C}\right)$. We also investigated the effects of yeast, lactic acid bacteria (LAB), and Bacillus spp. on fermentation and determined the results of their interactions during fermentation. The viable cells were observed within 8 days in single-strain fermentation. However, when feedstuffs were inoculated with a culture of mixed strains, LAB were predominant at low temperatures $\left(10^{\circ} \mathrm{C}\right.$ and $\left.20^{\circ} \mathrm{C}\right)$, while Bacillus spp. was predominant at high temperatures $\left(30^{\circ} \mathrm{C}\right.$ and $40^{\circ} \mathrm{C}$ ). A significant drop in $\mathrm{pH}$ from 6.5 to 4.3 was observed when LAB was the dominant strain in the culture, which correlated with the concentrations of lactic acid. Slight ethanol production was detected above $20^{\circ} \mathrm{C}$ regardless of the incubation temperature, suggesting active metabolism of yeast, despite this organism making up a marginal portion of the microbes in the mixed culture. These results suggested that fermentation temperature significantly affects microbiological profiles and biochemical parameters, such as $\mathrm{pH}$ and the lactic acid concentration, of fermented feedstuffs. Our data provide valuable information for the determination of industrial standards for fermented feedstuffs.

Keywords: Agricultural by-products, Fermented feeds, Saccharomyces cerevisiae, Bacillus subtilis, Lactobacillus plantarum

\section{INTRODUCTION}

Both supply and demand of feed ingredients are deteriorating due to climate change and increased de- 
Soo Rin Kim

https://orcid.org/0000-0001-5855-643X

Jeongman Seol

https://orcid.org/0000-0001-7832-6391

Uyeh Daniel Dooyum

https://orcid.org/0000-0003-1790-210X

Junhee Kim

https://orcid.org/0000-0001-6458-2378

Dong Hyuck Hong

https://orcid.org/0000-0002-9411-541X

Jong Nam Kim

https://orcid.org/0000-0002-8034-7156

Yushin $\mathrm{Ha}$

https://orcid.org/0000-0002-9434-8694

\section{Competing interests}

No potential conflict of interest relevant to

this article was reported.

Funding sources

This research was supported by the Basic Science Research Program through the

National Research Foundation of Korea

(NRF) funded by the Ministry of Education

(2018R1D1A1B07049186)

\section{Acknowledgements}

This research was supported by Basic

Science Research Program through

the National Research Foundation of

Korea(NRF) funded by the Ministry of

Education (2018R1D1A1B07049186).

Availability of data and material

Upon reasonable request, the datasets of this

study are available from the corresponding

author.

Authors' contributions

Conceptualization: Kim SR, Hong DH, Kim JN, $\mathrm{HaY}$.

Data curation: Woo S, Ye S, Seol J, Dooyum UD, Kim J.

Formal analysis: Woo S, Ye S, Seol J, Dooyum UD, Kim J.

Methodology: Woo S, Ye S, Seol J,

Dooyum UD, Kim J.

Software: Ye S, Seol J.

Validation: Ye S, Seol J.

Investigation: Ye S, Seol J.

Writing - original draft: Woo S, Kim S, Ye S, Seol J, Kim JN.

Writing - review \& editing: Kim S, Kim JN

Ethics approval and consent to participate This article does not require IRB/IACUC approval because there were no human and animal participants. mand for biofuel production. This has become a major concern to the domestic livestock industry in feedstuff-importing countries [1]. In order to resolve this problem, several attempts have been made to use agricultural by-products generated during agricultural food processing, and various studies have been conducted on utiliztation of by-products as a value-added feedstuff [1-5]. However, the digestibility of agricultural by-products by livestock is low. Fermentation is one processing method that can improve the digestibility $[1,3,5,6]$.

Fermented feedstuffs are produced by inoculating microorganisms into digestible or non-digestible feedstock, which mainly comprises agricultural by-products [6]. The fermented feedstuffs act as probiotics because they contain beneficial microorganisms. Moreover, biological additives have attracted attention as antibiotic substitutes after the prohibition of antibiotic use in animals [7-10].

Several microbial species, such as Lactobacillus spp., Streptococcus spp., Bacillus spp., Clostridium spp., Bifidobacterium spp., Enterococcus spp., Saccharomyces cerevisiae, and Aspergillus oryzae have been utilized for fermentation of feedstuffs [11,12]. Among them, S. cerevisiae, Lactobacillus plantarum, and Bacillus subtilis are widely used as biological additives because of their beneficial effects. S.cerevisiae possesses a high oxygen affinity and hence stimulates the growth of anaerobic microorganisms in the rumen by increasing oxygen absorption in the gut $[7,9,13]$. It also stabilizes gastric and intestinal $\mathrm{pH}$ and increases animal weight gain by improving fiber digestibility [14-17]. It has been reported that probiotic feed reduces harmful microorganisms in the intestine, increases beneficial microorganisms by improving the gut microenvironment [12], enhances digestion and absorption of feed, and reduces odor emissions from manure $[18,19]$. Furthermore, S. cerevisiae has mycotoxin removal ability and can tolerate salivary and gastrointestinal environments [20]. Ethanol produced by $S$. cerevisiae accounts for a large portion of fermentation metabolites and increases the true metabolizable energy content [21] and feed palatability [22].

L. plantarum, a lactic acid bacteria (LAB), is one of the best suited lactic acid-producing species for decreasing feedstock $\mathrm{pH}$ [23], and thus can be implemented for extending shelf-life and decreasing nutritional loss in feeds [19]. Moreover, LAB with high intestinal adhesiveness block attachment of harmful organisms to the gut and repress the growth of noxious bacteria through production of antibacterial proteins [7-9]. In addition, they contribute to improved resistance to diseases and infections [24].

Bacillus spp. can survive easily because their spores are resistant to heat, light, and variations in $\mathrm{pH}$, and the bacteria can provide protection against pathogens by producing antipathogenic substances $[13,25]$. Furthermore, Bacillus spp. have been shown to enhance amino acid absorption and reduce insoluble polysaccharides in feedstuffs [26].

To maximize the benefits of fermented feedstuffs, suitable fermentation conditions must be identified and optimized accordingly, based on microorganism species and incubation temperature and time. Korea, in particular, has four distinct seasons and the average daily temperature changes with each season. Temperature plays a critical role in fermentation, and thus, fermentation conditions should be changed according to the season. Currently, many studies on the types of microorganisms used in fermentation of feeds are ongoing, but studies on fermentation temperatures and duration are lacking $[18,19,27]$. Therefore, it is necessary to study culture temperature and time.

In this study, fermented feedstuffs were prepared by incubation with three microorganisms at different temperatures corresponding to the four seasons in Korea. Two types of experiments were performed. One experiment involved single-strain fermentation with S. cerevisiae, L. plantarum, or $B$. subtilis, and the other involved fermentation with all three strains. The changes in viable cell count of the inoculated microorganisms and concentrations of the metabolites produced during fermentation were analyzed at different temperatures to provide reference data for seasonal fermented feedstuff production. 


\section{MATERIALS AND METHODS}

\section{Strains, media, and culture conditions}

S. cerevisiae ATCC18824 was grown in yeast extract peptone glucose (2\%) medium (YPD) (10 g/L yeast extract and $20 \mathrm{~g} / \mathrm{L}$ peptone); the solid medium was prepared by adding $20 \mathrm{~g} / \mathrm{L}$ bacto agar, and $100 \mu \mathrm{g} / \mathrm{mL}$ ampicillin (Amresco, Batavia, IL, USA) and $50 \mu \mathrm{g} / \mathrm{mL}$ kanamycin (Amresco, Batavia, IL, USA) were added to solid media for the detection of yeast in the mixed-strain fermentation. L. plantarum ATCC14917 was grown in De Man, Rogosa and Sharpe (MRS) medium; the solid medium was made by adding $20 \mathrm{~g} / \mathrm{L}$ bacto agar, and $0.002 \mathrm{~g} / \mathrm{L}$ sodium azide was added for the detection of LAB in the mixed-strain fermentation. B. subtilis ATCC6051 was grown on mannitol egg yolk polymyxin (MYP) agar as required. Precultured strains were grown overnight at $30^{\circ} \mathrm{C}$ and $250 \mathrm{rpm}$ in shaking incubator.

\section{Feedstuff preparation}

In order to produce fermented feedstuffs, raw materials were prepared by mixing molasses, rice bran, crushed corn, and wheat bran at a ratio of 0.7:2:2:2.7, based on guidelines provided by the Korea Federation of Livestock Cooperative in Yeongcheon. The chemical compositions of the raw materials used are shown in Table 1.

Rice bran, crushed corn, and wheat bran were mixed and pasteurized by autoclaving at $90^{\circ} \mathrm{C}$ for $15 \mathrm{~min}$. Molasses was mixed with water. Water was then added to the raw materials (initial moisture content of 9.5\%) to achieve an optimal moisture content of $45 \%$. The density of the feedstuff was $0.7 \mathrm{~kg} / \mathrm{m}^{3}$. The raw materials for manufacturing feedstuffs were suppliedby total mixed fermentation (TMF) feedstuff factory of the Korea Federation of Livestock cooperative in Yeongcheon.

\section{Feedstuff fermentation and microbiological analysis}

S. cerevisiae $\left(\mathrm{OD}_{600}=3.0\right)$, L. plantarum $\left(\mathrm{OD}_{600}=1.0\right)$, and B. subtilis $\left(\mathrm{OD}_{600}=2.5\right)$ were inoculated into the feedstuff at $0.5 \%$ weight. After mixing, $35 \mathrm{~g}$ of this mixture was added to a $50 \mathrm{~mL}$ conical tube to a density of $0.7 \mathrm{~kg} / \mathrm{m}^{3}$ and then cultured at $10^{\circ} \mathrm{C}, 20^{\circ} \mathrm{C}, 30^{\circ} \mathrm{C}$, or $40^{\circ} \mathrm{C}$ for 10 days. All experiments were repeated independently in triplicate, and variances are indicated with error bars.

To $140 \mathrm{~mL}$ of sterilized distilled water, $35 \mathrm{~g}$ of fermented feedstuffs was added, and the mixture was serially diluted to $10^{-2}, 10^{-4}$ and $10^{-6}$ in sterilized water. Yeast colonies, which included the inoculated S. cerevisiae, were counted after plating on YPD agar containing ampicillin and kanamycin and incubation at $30^{\circ} \mathrm{C}$ for $48 \mathrm{~h}$. The LAB colonies, which included inoculated L. plantarum, were counted after plating on MRS agar containing sodium azide and incubation at $37^{\circ} \mathrm{C}$ for $48 \mathrm{~h} . \mathrm{Ba}-$ cillus spp. colonies, which included inoculated B. subtilis, were counted after plating on MYP agar and incubation at $37^{\circ} \mathrm{C}$ for $48 \mathrm{~h}$. Colonies were counted to determine the numbers of viable micro-

Table 1. Chemical composition of feedstuff raw materials used in this study

\begin{tabular}{|c|c|c|c|c|c|c|c|c|c|c|c|c|c|c|c|c|c|}
\hline & $\begin{array}{c}\text { Met } \\
\text { (g) }\end{array}$ & $\begin{array}{l}\text { Lys } \\
\text { (g) }\end{array}$ & $\begin{array}{c}\text { Arg } \\
\text { (g) }\end{array}$ & $\begin{array}{l}\text { Thr } \\
\text { (g) }\end{array}$ & $\begin{array}{c}\text { Leu } \\
\text { (g) }\end{array}$ & $\begin{array}{l}l e \\
(g)\end{array}$ & $\begin{array}{l}\text { Val } \\
\text { (g) }\end{array}$ & $\begin{array}{l}\text { His } \\
\text { (g) }\end{array}$ & $\begin{array}{c}\text { Phe } \\
\text { (g) }\end{array}$ & $\begin{array}{l}\text { Trp } \\
\text { (g) }\end{array}$ & $\begin{array}{c}\mathrm{ME} \\
\text { (Mcal/g) }\end{array}$ & $\begin{array}{l}\mathrm{Ca} \\
\text { (g) }\end{array}$ & $\begin{array}{c}P \\
(g)\end{array}$ & $\begin{array}{l}\text { DM } \\
(\%)\end{array}$ & $\begin{array}{l}\text { MC } \\
(\%)\end{array}$ & $\begin{array}{c}\text { TDN } \\
(\mathrm{g})\end{array}$ & $\begin{array}{l}\text { CP } \\
\text { (g) }\end{array}$ \\
\hline Rice bran & 18.8 & 43.1 & 70.1 & 35.0 & 66.4 & 32.8 & 49.6 & 25.5 & 43.8 & 8.8 & $2,530.0$ & 0.8 & 17.3 & 88.3 & 11.8 & 768.0 & 131.0 \\
\hline Corn & 11.2 & 16.5 & 18.2 & 28.0 & 107.0 & 26.9 & 37.5 & 20.6 & 36.5 & 3.7 & $3,180.0$ & 0.3 & 3.2 & 87.3 & 12.7 & 780.0 & 70.0 \\
\hline Molasses & 0.0 & 0.0 & 0.0 & 0.0 & 0.0 & 0.0 & 0.0 & 0.0 & 0.0 & 0.0 & $2,170.0$ & 10.0 & 1.0 & 64.4 & 35.6 & 480.0 & 50.0 \\
\hline Wheat & 9.8 & 30.0 & 43.3 & 28.2 & 136.0 & 39.8 & 45.0 & 22.3 & 48.4 & 10.6 & $3,070.0$ & 0.7 & 3.3 & 88.3 & 11.7 & 740.0 & 110.0 \\
\hline
\end{tabular}

Chemical compositions per $1 \mathrm{~kg}$ each material (rice bran, corn, molasses, and wheat).

Met, methionine; Lys, lysine; Arg, arginine; Thr, threonine; Leu, leucine; lle, isoleucine; Val, valine; His, histidine; Phe, phenylalanine; Trp, tryptophan; ME, metabolized energy; Ca, calcium; $\mathrm{P}$, phosporous; DM, dried matter; $\mathrm{MC}$, moisture content; TDN, total digestible nutrients; $\mathrm{CP}$, crude protein. 
organisms, and values are represented as colony-forming units (CFU)/g fresh matter.

\section{Analytical methods}

Cell growth was monitored at an optical density (OD) of $600 \mathrm{~nm}$ using a spectrophotometer (OPTIZEN NANO Q, Neogen, Sejong, Korea). A $1 \mathrm{~mL}$ sample of fermented feedstuff was used to measure the $\mathrm{pH}$ (Seven compact ${ }^{\mathrm{TM}} \mathrm{pH} /$ Ion meter S220, Mettler Toledo, Columbus, Ohio, USA) after a $10^{-1}$ dilution in sterilized water. Concentrations of lactic acid, acetic acid, and ethanol were detected using a high-performance liquid chromatograph (HPLC; Agilent 1260 series, Agilent Technologies, Santa Clara, CA, USA) equipped with a refractive detector and a Rezex ROA-Organic Acid $\mathrm{H}^{+}(8 \%)$ column (Phenomenex, Torrance, $\left.\mathrm{CA}, \mathrm{USA}\right)$. The column was eluted with 0.005 $\mathrm{N}$ of $\mathrm{H}_{2} \mathrm{SO}_{4}$ at a flow rate of $0.6 \mathrm{~mL} / \mathrm{min}$ at $50^{\circ} \mathrm{C}$.

\section{RESULTS}

\section{Viable cell counts at different temperatures}

Feedstuffs were inoculated with a single strain, and the number of viable cells was counted for each strain at $10^{\circ} \mathrm{C}, 20^{\circ} \mathrm{C}, 30^{\circ} \mathrm{C}$, and $40^{\circ} \mathrm{C}$ in order to analyze the effect of fermentation temperature. When each strain was inoculated at $0.5 \%$ (g dry cells/g feeds), the initial viable cell counts were confirmed to be in the range of 4.4 to $6.7 \mathrm{Log}$ CFU/g. Even though we inoculated a single $S$. cerevisiae, L. plantarum or B. subtilis strain for single fermentation, there was the possibility of mixed strains in the fermented feedstuffs because the material was pasteurized and not sterilized before inoculation.

The viable cell counts of each species increased and reached a peak within 3 days, except for those from the samples incubated at $10^{\circ} \mathrm{C}$, and the cell counts gradually decreased after 3 days. At $20^{\circ} \mathrm{C}$, the final viable cell counts of the three species were similar to the initial cell numbers (Fig. 1B). However, at $30^{\circ} \mathrm{C}$, the viable cell counts of $\mathrm{LAB}$ declined below the initial cell number after day 7 (Fig. 1C). At $40^{\circ} \mathrm{C}$, yeast and $\mathrm{LAB}$ cell numbers dropped significantly below the initial cell number, and only Bacillus spp. persisted at the initial viable cell count (Fig. 1D). However, at $10^{\circ} \mathrm{C}$, cell growth patterns were quite different than those at the other temperatures. The viable cell counts of each strain were not markedly increased, and only Bacillus spp. viable cell numbers slowly increased after 5 days. Moreover, no viable cell counts of yeast were detected after 10 days (Fig. 1A), suggesting that $10^{\circ} \mathrm{C}$ was not suitable for the proliferation of all three microorganisms (yeast, Bacillus spp., and $\mathrm{LAB}$ ).

The $\mathrm{LAB}$ viable cell counts reached a peaked within 2 days and decreased steadily after 3 days at $20^{\circ} \mathrm{C}, 30^{\circ} \mathrm{C}$, and $40^{\circ} \mathrm{C}$. However, at $10^{\circ} \mathrm{C}$, the viable cell number remained slightly increased after 3 days. LAB viable cell numbers reached the highest value of $10.4 \mathrm{Log} \mathrm{CFU} / \mathrm{g}$ at $20^{\circ} \mathrm{C}$ (Fig. 1). Bacillus spp. showed a similar growth pattern to $L A B$ at all temperatures. The viable cell counts of Bacillus spp. were nearly equal to those of $\mathrm{LAB}$ at $20^{\circ} \mathrm{C}, 30^{\circ} \mathrm{C}$, and $40^{\circ} \mathrm{C}$. However, Bacillus spp. maintained numbers of at least $6 \mathrm{Log} \mathrm{CFU} / \mathrm{g}$ at all tested temperatures throughout the fermentation process, unlike LAB and yeast (Fig. 1). Although yeast numbers did not exceed $10^{8} \mathrm{CFU} /$ $\mathrm{g}$ at any temperature, yeast viability was sustained at $20^{\circ} \mathrm{C}$ and $30^{\circ} \mathrm{C}$ throughout the fermentation process. At $10^{\circ} \mathrm{C}$ and $40^{\circ} \mathrm{C}$, the viable cell numbers decreased slowly, and no growth was detected at day 10 of fermentation at $10^{\circ} \mathrm{C}$. These results reveal that incubation temperature affects the growth profile of this species.

It has been reported that yeast growth is inhibited by lactic acid produced by LAB [28-31]. In accordance with previous studies, our results also show that yeast numbers did not increase after the growth of LAB under all tested conditions (Fig. 1). Moreover, fermentation was completed by 
A

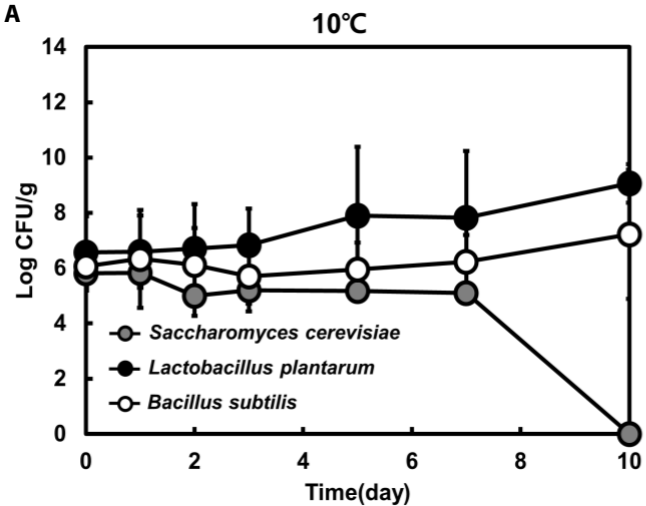

C

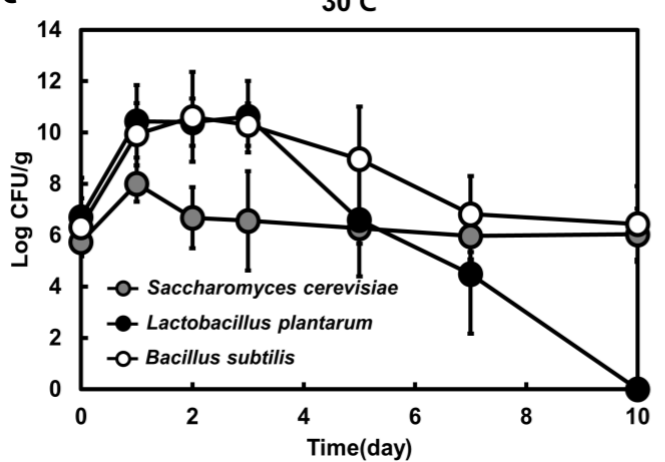

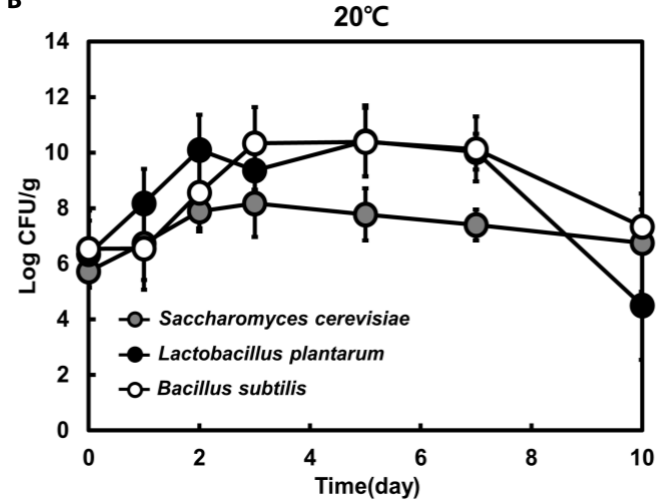

D

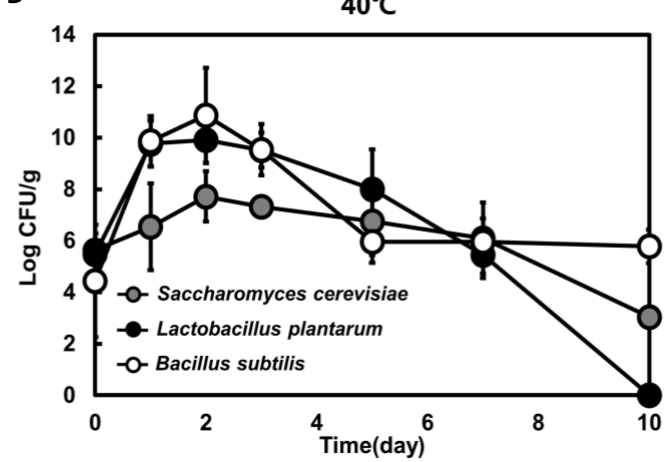

Fig. 1. Viable cell counts of microorganisms in single-strain fermentation at different temperatures. Growth of microorganisms at $(\mathrm{A}) 10^{\circ} \mathrm{C},(\mathrm{B}) 20^{\circ} \mathrm{C},(\mathrm{C})$ $30^{\circ} \mathrm{C}$, and (D) $40^{\circ} \mathrm{C}$.

7 days, at which point the cell numbers of all strains dropped sharply. Bacillus spp. strains showed increased proliferation at high temperatures, due to their heat-resistant spores $[18,25]$.

\section{The interaction among three microorganisms during mixed-strain fermentation}

Next, we analyzed mixed-strain fermentation and investigated the interaction among all three strains (yeast, Bacillus spp., and LAB) based on viable cell counts during feed fermentation at different temperatures. The fermentation pattern was changed after 3 days and the growth of most species was highest within 2 days.

There was no significant difference in growth patterns between single- and mixed-strain fermentation at $10^{\circ} \mathrm{C}$ and $40^{\circ} \mathrm{C}$ (Fig. 2). However, the proportion of each strain in the mixed-strain culture was different from that in the single-strain culture at favorable temperatures (i.e., $20^{\circ} \mathrm{C}$ or $30^{\circ} \mathrm{C}$ ). Similar to the single-strain fermentation, $\mathrm{LAB}$ was the dominant strain at $10^{\circ} \mathrm{C}, 20^{\circ} \mathrm{C}$, and $30^{\circ} \mathrm{C}$ in mixed fermentation until day 3 (Fig. 3A, B, and C). However, after day 3, the mixed-strain culture at $30^{\circ} \mathrm{C}$ was primarily comprised of yeast and Bacillus spp. (Fig. 3C).

Bacillus spp. was the dominant species in the late phase of fermentation at $30^{\circ} \mathrm{C}$ and in the early phase of fermentation at $40^{\circ} \mathrm{C}$, indicating that the portion of Bacillus spp. was dominant at higher temperatures (Fig. 3C and D). Although the portion of yeast were markedly increased from day 5 to 7 at $30^{\circ} \mathrm{C}$ in mixed fermentation, yeast was not the dominant species in mixed fermentation.

\section{$\mathrm{pH}$ changes during fermentation at different temperatures}

For both single and mixed fermentation at $10^{\circ} \mathrm{C}, 20^{\circ} \mathrm{C}, 30^{\circ} \mathrm{C}$, and $40^{\circ} \mathrm{C}$, we monitored $\mathrm{pH}$ levels (Fig. 4). The initial $\mathrm{pH}$ of the feedstuffs was approximately 6.5, and the $\mathrm{pH}$ dropped instantly or 

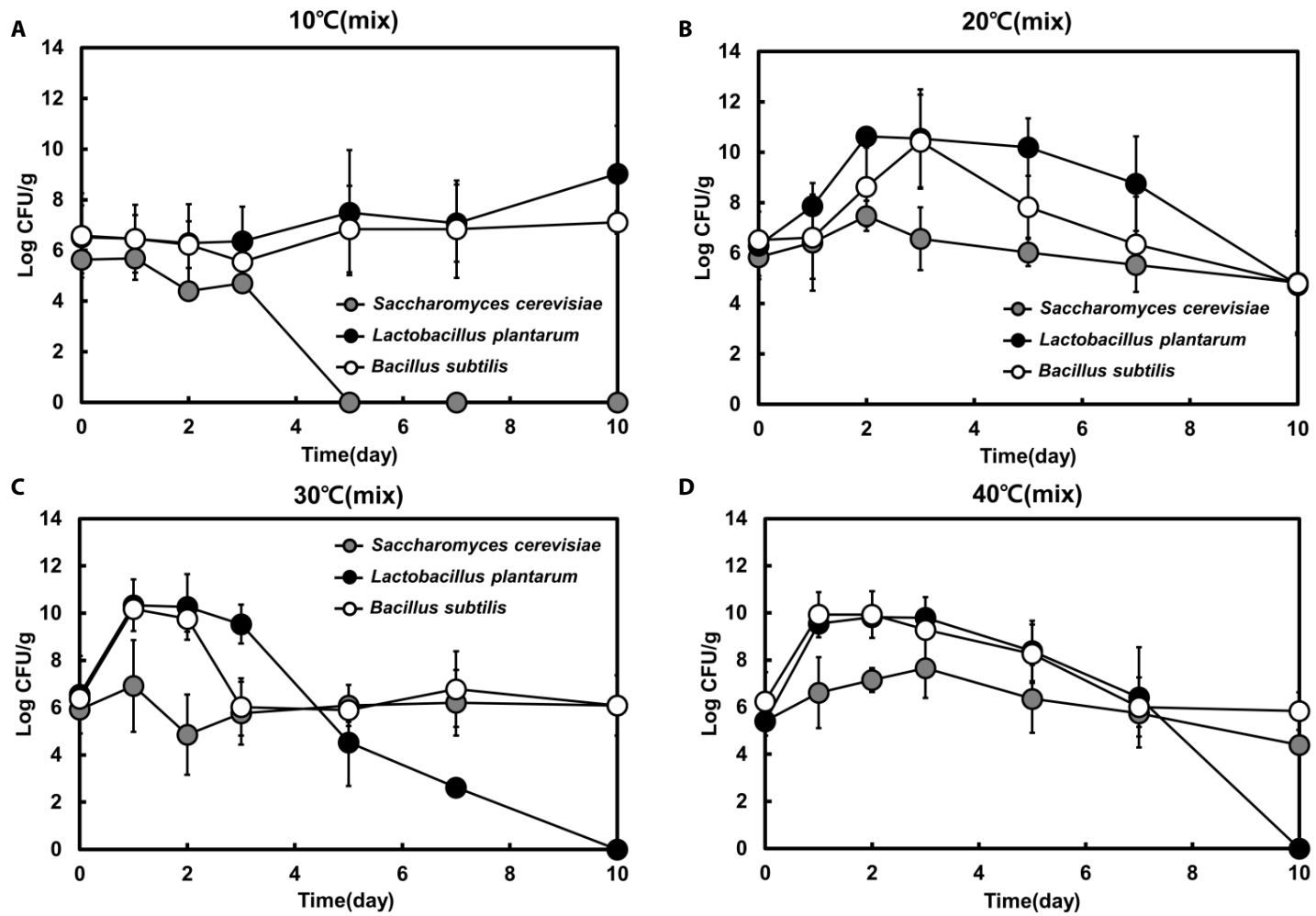

Fig. 2. Viable cell counts of microorganisms in mixed-strain fermentation at different temperatures. Growth of microorganisms at $(A) 10^{\circ} \mathrm{C},(B) 20^{\circ} \mathrm{C},(\mathrm{C})$ $30^{\circ} \mathrm{C}$, and (D) $40^{\circ} \mathrm{C}$.
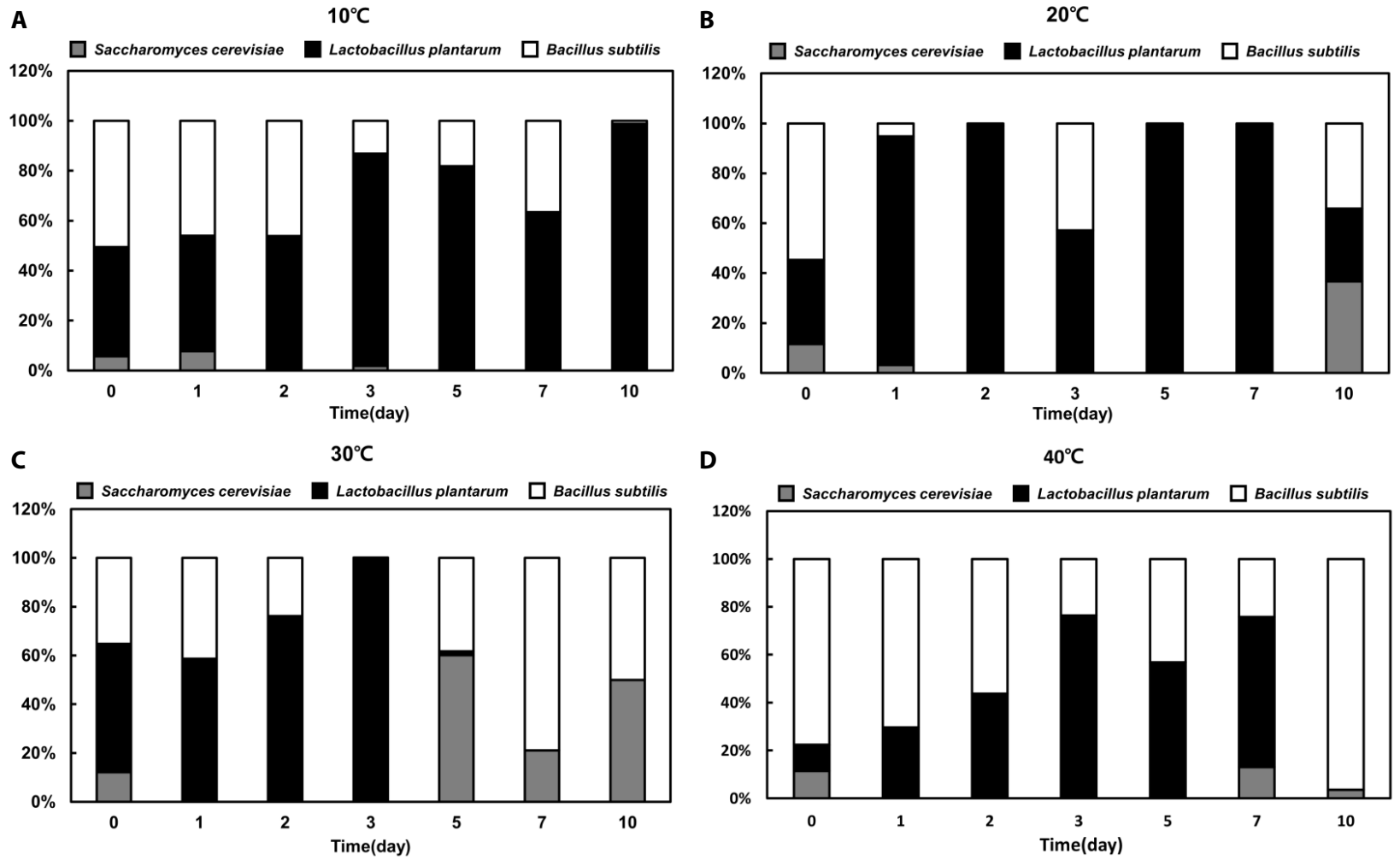

Fig. 3. Relative proportion of each strain in mixed-strain fermentation at different temperatures. Growth of microorganisms at $(\mathrm{A}) 10^{\circ} \mathrm{C},(\mathrm{B}) 20^{\circ} \mathrm{C},(\mathrm{C})$ $30^{\circ} \mathrm{C}$, and (D) $40^{\circ} \mathrm{C}$. 
A

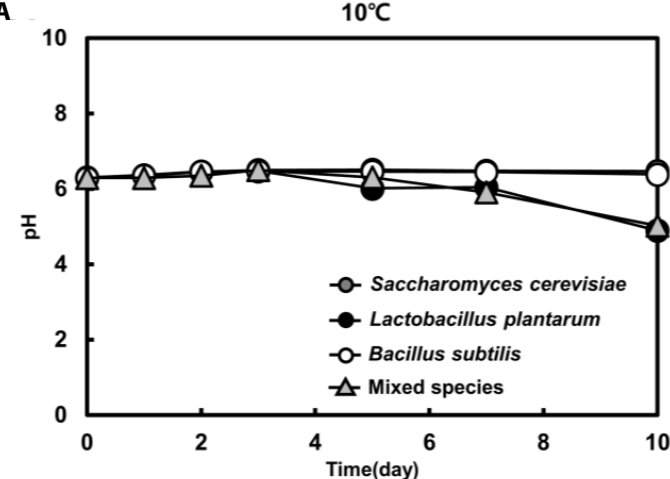

C

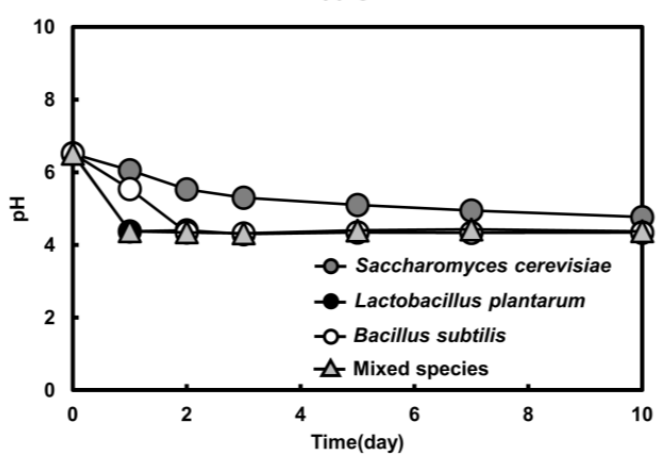

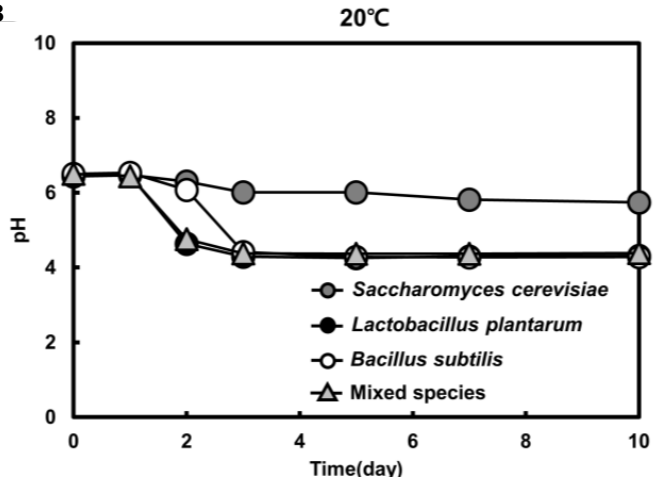

D

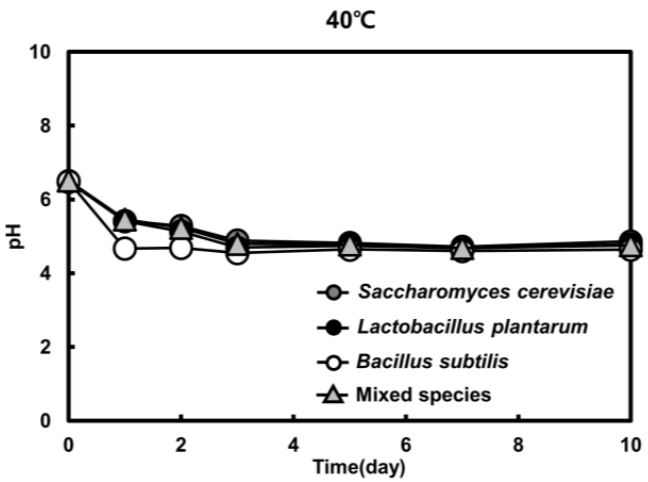

Fig. 4. $\mathrm{pH}$ changes in single-strain and mixed-strain fermentation at different temperatures. Growth of microorganisms at $(\mathrm{A}) 10^{\circ} \mathrm{C},(\mathrm{B}) 20^{\circ} \mathrm{C},(\mathrm{C}) 30^{\circ} \mathrm{C}$, and (D) $40^{\circ} \mathrm{C}$. Circle, $\mathrm{pH}$ of single-strain fermentation with each strain; Triangle, $\mathrm{pH}$ of mixed-strain fermentation.

gradually to about $\mathrm{pH} 4.3$ at all tested temperatures. Once the $\mathrm{pH}$ decreased to approximately 4.3, the $\mathrm{pHs}$ were not further changed. At $40^{\circ} \mathrm{C}$, all feedstuffs reached $\mathrm{pH} 4.3$ in the early stage of fermentation (day 1), but at $10^{\circ} \mathrm{C}$, the $\mathrm{pH}$ had barely reached 4.3 in the last stage of fermentation (day 10) (Fig. 4). Moreover, the $\mathrm{pH}$ level was maintained in single- yeast fermentation at $20^{\circ} \mathrm{C}$, while the $\mathrm{pH}$ declined significantly in single LAB and Bacillus spp. fermentations after 3 days. Interestingly, the pattern of $\mathrm{pH}$ level in the mixed fermentation was similar with that of the single LAB strain fermentation, suggesting that $\mathrm{LAB}$ was the dominat strain (Fig. 3).

The decrease in $\mathrm{pH}$ may be attributed to the production of organic acids such as lactic acid, acetic acid, and propionic acid, as reported in previous feed fermentation studies [19,23]. The maintenance of a $\mathrm{pH}$ level of 4.3 can be explained by LAB utilization of sugars originating from hemicellulose breakdown, causing a decrease in $\mathrm{pH}$ [23].

\section{Metabolite analysis}

To cleary identify optimal fermentation conditions, we also analyzed the changes in levels of metabolites such as lactic acid, acetic acid, and ethanol, which are generally used to assess the quality of fermented feedstuffs [32-38], in single- and mixed- culture fermentation.

Lactic acid, which is one of the representative organic acids of fermented feedstuffs, was produced in the early stages of both types of fermentation at $20^{\circ} \mathrm{C}, 30^{\circ} \mathrm{C}$, and $40^{\circ} \mathrm{C}$. The highest lactic acid concentration was 11.1 and $8.9 \mathrm{~g} / \mathrm{L}$ for single and mixed fermentation at $20^{\circ} \mathrm{C}$, respectively (Fig. $5 \mathrm{~A}$ and $\mathrm{B}$ ). On the other hand, at $10^{\circ} \mathrm{C}$, lactic acid was produced after 5 days, and the concentration was very low $(2.7 \mathrm{~g} / \mathrm{L})$ in both the single and mixed fermentation (Fig. $5 \mathrm{~A}$ and $\mathrm{B})$. The overall results show that lactic acid production in mixed fermentation was relatively lower than that in the 
A

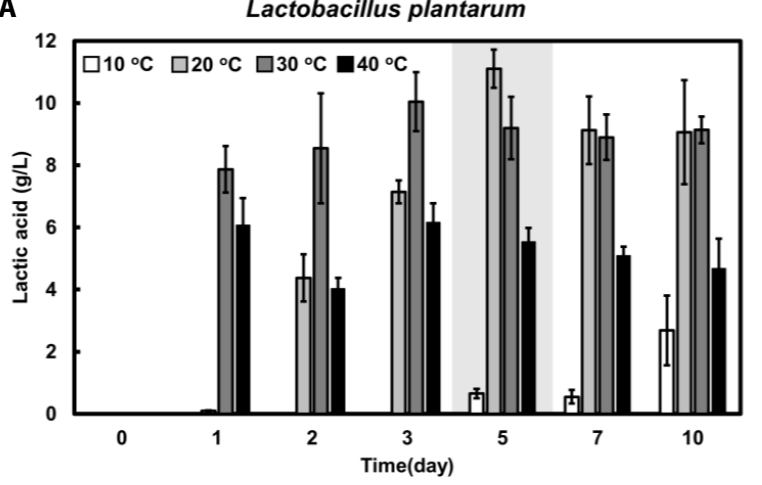

C

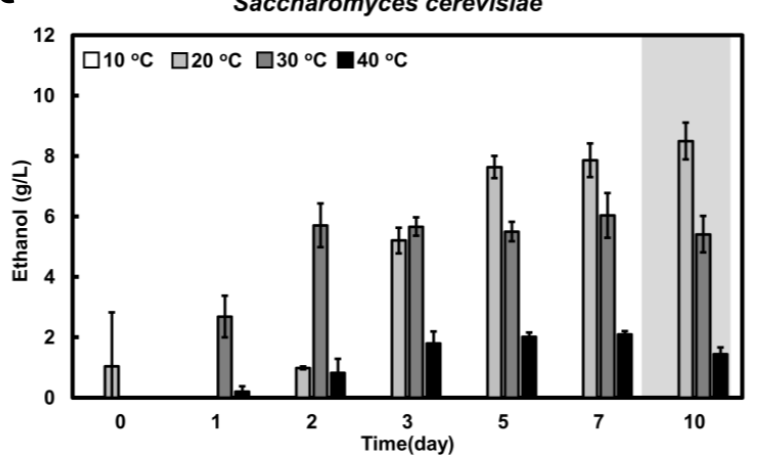

B

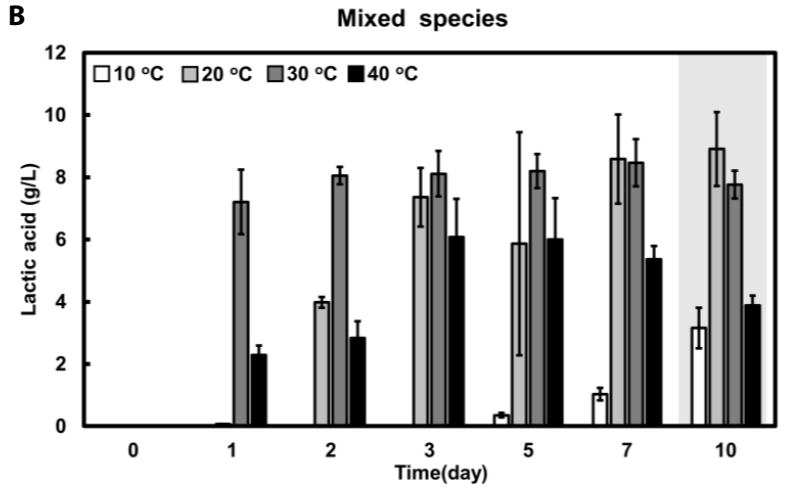

D

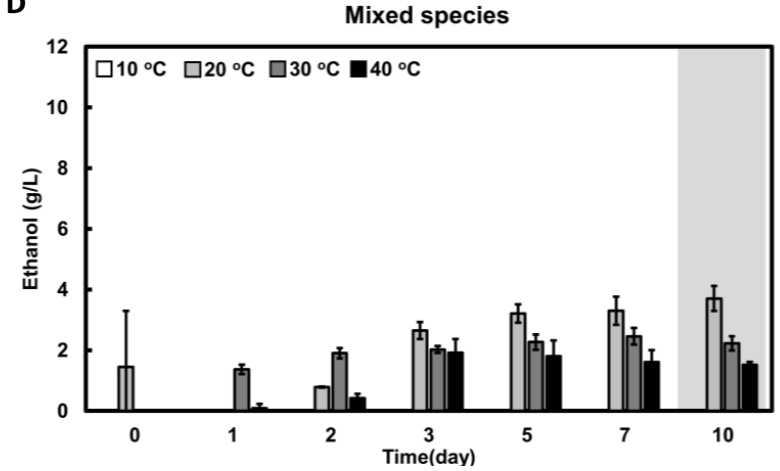

Fig. 5. Lactic acid and ethanol production in single-strain and mixed-strain fermentation. (A) Lactic acid production by Lactobacillus plantarum in singlestrain fermentation, (B) Lactic acid production in mixed-strain fermentation, (C) Ethanol production by Saccharomyces cerevisiae in single-strain fermentation, (D) Ethanol production in mixed-strain fermentation.

single-strain fermentation.

The level of ethanol increased constantly during the fermentation process in the single and mixed fermentations at $20^{\circ} \mathrm{C}$, reaching a maximum level of 8.5 and $3.7 \mathrm{~g} / \mathrm{L}$, respectively (Fig. $5 \mathrm{C}$ and D). At $30^{\circ} \mathrm{C}$, the level of ethanol was not significantly changed after day $2(5.4-6.0 \mathrm{~g} / \mathrm{L})$. Ethanol was not produced at $10^{\circ} \mathrm{C}$ and only slightly produced at $40^{\circ} \mathrm{C}$ in both fermentations (Fig. $5 \mathrm{C}$ and $\mathrm{D})$. The overall results indicated that ethanol production was substantially higher in single-strain fermentation than in mixed-strain fermentation at all tested temperatures. In addition, the effect of temperature on ethanol production was much greater in single-strain fermentation than in mixed-strain fermentation.

Acetic acid production was highest at $40^{\circ} \mathrm{C}$, and there was no difference between acetic acid levels of the single-strain and mixed-strain fermentation (data not shown). With regards to the concentration of metabolites such as organic acids and ethanol, single-strain fermentation was found to be more advantageous than mixed-strain fermentation (Fig. 5B and D).

The results reveal that the optimal fermentation conditions for maximal lactic acid and ethanol production were single-strain fermentation at $20^{\circ} \mathrm{C}$ for 7 days. The representative results of the metabolite concentrations and viable cell numbers at day 7 are shown in Table 2. Moreover, our results show that more time is required to maximize the benefits of fermented feeds incubated at lower temperatures. At low and high temperatures, yeast growth and metabolism is inhibited [39-41]. The higher level of metabolites in single-strain fermentation, as compared to mixed-strain fermentation, could be caused by the competing interaction between the species in the mixed-strain fermentation environment $[28,42]$. 


\begin{tabular}{|c|c|c|c|c|c|c|c|c|c|}
\hline \multirow{2}{*}{\multicolumn{2}{|c|}{ Temperature $\left({ }^{\circ} \mathrm{C}\right)$}} & \multicolumn{4}{|c|}{ Single fermentation } & \multicolumn{4}{|c|}{ Mixed fermentation } \\
\hline & & \multirow{2}{*}{$\frac{10}{5.1^{\mathrm{a}}}$} & \multirow{2}{*}{$\begin{array}{l}20 \\
7.4^{\mathrm{c}}\end{array}$} & \multirow{2}{*}{$\frac{30}{6.0^{b}}$} & \multirow{2}{*}{$\frac{40}{6.1^{b}}$} & \multirow{2}{*}{$\frac{10}{0.0^{\mathrm{a}}}$} & \multirow{2}{*}{$\frac{20}{5.5^{\mathrm{b}}}$} & \multirow{2}{*}{$\begin{array}{c}30 \\
6.2^{c}\end{array}$} & \multirow{2}{*}{$\begin{array}{r}40 \\
5.7^{b}\end{array}$} \\
\hline Viable cell count & S. cerevisiae & & & & & & & & \\
\hline (Log CFU/g) & L. plantarum & $7.8^{\mathrm{b}}$ & $10.0^{c}$ & $4.5^{\mathrm{a}}$ & $5.5^{\mathrm{a}}$ & $7.1^{\mathrm{c}}$ & $8.8^{d}$ & $2.6^{\mathrm{a}}$ & $6.4^{\mathrm{b}}$ \\
\hline & B. subtilis & $6.2^{b}$ & $10.1^{\mathrm{d}}$ & $6.8^{c}$ & $6.0^{\mathrm{a}}$ & $6.8^{d}$ & $6.4^{\mathrm{ab}}$ & $6.8^{\mathrm{bc}}$ & $6.0^{\mathrm{a}}$ \\
\hline \multirow[t]{3}{*}{$\mathrm{pH}$} & S. cerevisiae & $6.5^{\mathrm{d}}$ & $5.8^{c}$ & $5.0^{b}$ & $4.7^{\mathrm{a}}$ & & & & \\
\hline & L. plantarum & $6.1^{\mathrm{c}}$ & $4.3^{\mathrm{a}}$ & $4.3^{\mathrm{a}}$ & $4.7^{\mathrm{b}}$ & $5.9^{c}$ & $4.4^{\mathrm{a}}$ & $4.4^{\mathrm{a}}$ & $4.7^{\mathrm{b}}$ \\
\hline & B. subtilis & $6.5^{\mathrm{d}}$ & $4.3^{\mathrm{a}}$ & $4.3^{b}$ & $4.6^{\mathrm{c}}$ & & & & \\
\hline \multirow[t]{3}{*}{ Lactic acid (g/L) } & S. cerevisiae & $0.0^{\mathrm{a}}$ & $0.8^{\mathrm{a}}$ & $4.8^{b}$ & $4.9^{b}$ & & & & \\
\hline & L. plantarum & $0.5^{\mathrm{a}}$ & $9.1^{\mathrm{c}}$ & $8.9^{c}$ & $5.1^{\mathrm{b}}$ & $1.0^{\mathrm{a}}$ & $8.6^{c}$ & $8.5^{c}$ & $5.4^{\mathrm{b}}$ \\
\hline & B. subtilis & $0.0^{\mathrm{a}}$ & $11.0^{\mathrm{d}}$ & $9.0^{c}$ & $6.1^{\mathrm{b}}$ & & & & \\
\hline \multirow[t]{3}{*}{ Acetic acid (g/L) } & S. cerevisiae & $0.0^{\mathrm{a}}$ & $0.5^{\mathrm{ab}}$ & $1.1^{b}$ & $1.8^{\mathrm{c}}$ & & & & \\
\hline & L. plantarum & $0.0^{\mathrm{a}}$ & $0.6^{b}$ & $0.3^{\mathrm{ab}}$ & $1.9^{\mathrm{c}}$ & $0.0^{\mathrm{a}}$ & $0.8^{b}$ & $0.3^{\mathrm{a}}$ & $1.7^{\circ}$ \\
\hline & B. subtilis & $0.0^{\mathrm{a}}$ & $0.9^{b}$ & $0.8^{b}$ & $1.7^{\mathrm{c}}$ & & & & \\
\hline \multirow[t]{3}{*}{ Ethanol (g/L) } & S. cerevisiae & $0.0^{\mathrm{a}}$ & $7.9^{d}$ & $6.0^{c}$ & $2.1^{b}$ & & & & \\
\hline & L. plantarum & $0.0^{\mathrm{a}}$ & $1.7^{\mathrm{b}}$ & $2.2^{c}$ & $2.1^{\mathrm{bc}}$ & $0.0^{\mathrm{a}}$ & $3.3^{\mathrm{c}}$ & $2.5^{\mathrm{bc}}$ & $1.6^{\mathrm{b}}$ \\
\hline & B. subtilis & $0.0^{\mathrm{a}}$ & $1.8^{\mathrm{c}}$ & $2.7^{d}$ & $1.3^{b}$ & & & & \\
\hline
\end{tabular}

${ }^{a-d}$ Significant differences (Turkey's test, $\left.p<0.05\right)$ between four temperature conditions $\left(10^{\circ} \mathrm{C}, 20^{\circ} \mathrm{C}, 30^{\circ} \mathrm{C}\right.$, and $40^{\circ} \mathrm{C}$ ).

S. cerevisiae, Saccharomyces cerevisiae; L. plantarum, Lactobacillus plantarum; B. subtilis, Bacillus subtilis.

\section{DISCUSSION}

There are no precise guidelines or standards for the fermentation of feedstuffs, and many studies have been conducted to optimize fermentation conditions. Among the various parameters used to estimate feedstuff quality, $\mathrm{pH}$ is an important parameter because various organic acids are produced by microorganisms during fermentation [43]. A pH value of 4.0 usually indicates that fermentation has been completed efficiently [18,44]. A low $\mathrm{pH}$ prevents growth of harmful organisms [42] and increases production of rapidly degradable carbohydrates [45]. In addition, viable cell count is an important parameter for fermented feedstuffs, as it indicates the ability of a culture to sustain fermentation, and animals benefit from ingestion of the microorganisms [46]. The use of probiotics increases beneficial gut microorganisms and reduces the number of harmful organisms in the intestine of ruminant animals [33]. Moreover, absorption and digestion are improved [47,48], and odor emissions from manure are decreased [44]. The S. cerevisiae, L. plantarum, and B. subtilis strains used in this study also function as probiotics.

Furthermore, organic acids such as lactic acid and acetic acid inhibit the growth of pathogenic bacteria $[42,48]$ and enhance mineral and nutrient utilization [49]. Organic acid production stimulates chewing rate and helps eliminate total hydrogen ions of gastric and intestine [50]. Ethanol stimulates appetite and improves palatability, which promotes weight gain [3].

Comprehensively, there were no major changes in metabolic parameters, such as organic acid and ethanol production, and the number of viable cells decreased rapidly after 7 days. Hence, the optimal fermentation time for feedstuffs is considered to be 7 days. Considering that the fermentation method requires modification in Korea according to the season in order to maximize the effects of fermented feeds, the four temperature conditions in this study correspond to the four seasons: $20^{\circ} \mathrm{C}$ and $30^{\circ} \mathrm{C}$ conditions represent spring, fall, and early summer temperatures, the $10^{\circ} \mathrm{C}$ condition represents winter temperature, and the $40^{\circ} \mathrm{C}$ condition represents summer.

This research provides fermentation data based on different temperatures corresponding to the 
four seasons in Korea and hence, can serve as a potential guideline for fermentation of feedstuffs. By using our results as a reference, the specific fermentation times required to produce fermented feedstuffs can be adjusted based on individual preferences between viable cell density and metabolites, such as organic acids. Furthermore, our findings contribute to building baseline data for fermented feedstuffs.

\section{REFERENCES}

1. Choi SH, Hwangbo S, Kim SW, Cho YM, Yoo YH, Kim TI, et al. Effects of fermented feed with agricultural by-products on the growth performance and nutrients utilization in fattening Korean black goats. J Korean Soc Grassl Forage Sci. 2012;32:49-58.

2. Kondo M, Kita K, Yokota Ho. Ensiled or oven-dried green tea by-product as protein feedstuffs: effects of tannin on nutritive value in goats. Asian-Australas J Anim Sci. 2007;20:880-6.

3. Kim CH, Park BK, Ohh SJ, Sung KI, Kim HS, Hong BJ, et al. Determination of optimum fermentation condition for alcohol-fermented feeds with wet Brewer's grains.J Anim Sci Technol. 2005;47:607-14.

4. Jeon S, Sohn KN, Seo S. Evaluation of feed value of a by-product of pickled radish for ruminants: analyses of nutrient composition, storage stability, and in vitro ruminal fermentation. J Anim Sci Technol. 2016;58:34.

5. Sun Y, Oba M. Effects of feeding a high-fiber byproduct feedstuff as a substitute for barley grain on rumen fermentation and productivity of dairy cows in early lactation. J Dairy Sci. 2014;97:1594-602.

6. Cho SB, Kim DW, Yang SH, Park KH, Choi DY, Yoo YH, et al. Establishment of producing conditions of fermentation feed for swine.J Anim Environ Sci. 2012;18:137-44.

7. Niba AT, Beal JD, Kudi AC, Brooks PH. Bacterial fermentation in the gastrointestinal tract of non-ruminants: influence of fermented feeds and fermentable carbohydrates. Trop Anim Health Prod. 2009;41:1393-407.

8. Blagojev N, Škrinjar M, Vesković-Moračanin S, Šošo V. Control of mould growth and mycotoxin production by lactic acid bacteria metabolites. Rom Biotechnol Lett. 2012;17:7219-26.

9. Lee EY, Lim JS. Effective feeding methods for the reduction of malodor and an increase in productivity in livestock. Korean J Microbiol Biotechnol. 2011;39:200-9.

10. Wanapat M, Kang S, Polyorach S. Development of feeding systems and strategies of supplementation to enhance rumen fermentation and ruminant production in the tropics. J Anim Sci Biotechnol. 2013;4:32.

11. Kung L Jr. Silage fermentation and additives. In: Proceedings of Alltech's 17th Annual Symposium; 2001.p. 145-59.

12. Yoon IK, Stern MD. Effects of Saccharomyces cerevisiae and Aspergillus oryzae cultures on ruminal fermentation in dairy cows. J Dairy Sci. 1996;79:411-7.

13. Elferink SJWHO, Driehuis F, Gottschal JC, Spoelstra SF. Silage fermentation processes and their manipulation. FAO Plant Prod Prot Pap. 2000;17-30.

14. García CCG, Mendoza MGD, González MS, Cobos PM, Ortega CME, Ramirez LR. Effect of a yeast culture (Saccharomyces cerevisiae) and monensin on ruminal fermentation and digestion in sheep. Anim Feed Sci Technol. 2000;83:165-70.

15. Guedes CM, Gonçalves D, Rodrigues MAM, Dias-da-Silva A. Effects of a Saccharomyces cerevisiae yeast on ruminal fermentation and fibre degradation of maize silages in cows. Anim Feed Sci Technol. 2008;145:27-40.

16. Dierick NA. Biotechnology aids to improve feed and feed digestion: enzymes and fermenta- 
tion. Arch Tierernahr. 1989;39:241-61.

17. Martin SA, Nisbet DJ. Effect of direct-fed microbials on rumen microbial fermentation. J Dairy Sci. 1992;75:1736-44.

18. Muck RE. Silage microbiology and its control through additives. R Bras Zootec. 2010;39:18391.

19. Ro YM, Lee GH, Park I, Kim WG, Han BH, You J, et al. Isolation and characterization of lactic acid bacteria for use as silage additives. Korean J Microbiol. 2016;52:444-54.

20. Pizzolitto RP, Armando MR, Combina M, Cavaglieri LR, Dalcero AM, Salvano MA. Evaluation of Saccharomyces cerevisiae strains as probiotic agent with aflatoxin B1 adsorption ability for use in poultry feedstuffs. J Environ Sci Health B. 2012;47:933-41.

21. Leske KL, Akavanichan O, Cheng T, Coon CN. Effect of ethanol extract on nitrogen-corrected true metabolizable energy for soybean meal with broilers and roosters. Poult Sci. 1991;70:892-5.

22. Daniel JL, Amaral RC, Sá Neto A, Cabezas-Garcia EH, Bispo AW, Zopollatto M, et al. Performance of dairy cows fed high levels of acetic acid or ethanol.J Dairy Sci. 2013;96:398-406.

23. Bolsen KK, Ashbell G, Weinberg ZG. Silage fermentation and silage additives-review. Asian-Australas J Anim Sci. 1996;9:483-94.

24. Agarwal N, Kamra DN, Chaudhary LC, Agarwal I, Sahoo A, Pathak NN. Microbial status and rumen enzyme profile of crossbred calves fed on different microbial feed additives. Lett Appl Microbiol. 2002;34:329-36.

25. Park HS, Jo SW, Yim EJ, Kim YS, Moon SH, Cho HS, et al. Isolation and characterization of a Bacillus spp. for manufacturing the feed additives in livestock. Korean J Microbiol. 2015;51:419-26.

26. Boroojeni FG, Kozłowski K, Jankowski J, Senz M, Wiśniewska M, Boros D, et al. Fermentation and enzymatic treatment of pea for turkey nutrition. Anim Feed Sci Technol. 2018;237:78-88.

27. Kim JG, Ham JS, Li YW, Park HS, Huh CS, Park BC. Development of a new lactic acid bacterial inoculant for fresh rice straw silage. Asian-Australas J Anim Sci. 2017;30:950-6.

28. Olstorpe M, Lyberg K, Lindberg JE, Schnürer J, Passoth V. Population diversity of yeasts and lactic acid bacteria in pig feed fermented with whey, wet wheat distillers' grains, or water at different temperatures. Appl Environ Microbiol. 2008;74:1696-703.

29. Driehuis F, Elferink SJ, Spoelstra SF. Anaerobic lactic acid degradation during ensilage of whole crop maize inoculated with Lactobacillus buchneri inhibits yeast growth and improves aerobic stability. J Appl Microbiol. 1999;87:583-94.

30. van Winsen RL, Urlings BA, Lipman LJ, Snijders JM, Keuzenkamp D, Verheijden JH, et al. Effect of fermented feed on the microbial population of the gastrointestinal tracts of pigs. Appl Environ Microbiol. 2001;67:3071-6.

31. Dunière L, Sindou J, Chaucheyras-Durand F, Chevallier I, Thévenot-Sergentet D. Silage processing and strategies to prevent persistence of undesirable microorganisms. Anim Feed Sci Technol. 2013;182:1-15.

32. Mohd-Setapar SH, Abd-Talib N, Aziz R. Review on crucial parameters of silage quality. APCBEE Procedia. 2012;3:99-103.

33. Cho SB, Kwon CH, Kim EJ. Effects of bacterial inoculants and organic acids on silage quality: meta-analysis. J Korean Soc Grassland Forage Sci. 2014;34:94-102.

34. Taylor CC, Ranjit NJ, Mills JA, Neylon JM, Kung L. The effect of treating whole-plant barley with Lactobacillus buchneri 40788 on silage fermentation, aerobic stability, and nutritive value for dairy cows.J Dairy Sci. 2002;85:1793-800. 
35. Tabacco E, Piano S, Revello-Chion A, Borreani G. Effect of Lactobacillus buchneri LN4637 and Lactobacillus buchneri LN40177 on the aerobic stability, fermentation products, and microbial populations of corn silage under farm conditions.J Dairy Sci. 2011;94:5589-98.

36. Ranjit NK, Kung L Jr. The effect of Lactobacillus buchneri, Lactobacillus plantarum, or a chemical preservative on the fermentation and aerobic stability of corn silage. J Dairy Sci. 2000;83:52635.

37. Fang J, Matsuzaki M, Suzuki H, Cai Y, Horiguchi KI, Takahashi T. Effects of lactic acid bacteria and urea treatment on fermentation quality, digestibility and ruminal fermentation of roll bale rice straw silage in wethers. Grassland Sci. 2012;58:73-8.

38. Kleinschmit DH, Schmidt RJ, Kung L Jr. The effects of various antifungal additives on the fermentation and aerobic stability of corn silage.J Dairy Sci. 2005;88:2130-9.

39. Morano KA, Grant CM, Moye-Rowley WS. The response to heat shock and oxidative stress in Saccharomyces cerevisiae. Genetics. 2012;190:1157-95.

40. Lewis JG, Learmonth RP, Watson K. Induction of heat, freezing and salt tolerance by heat and salt shock in Saccharomyces cerevisiae. Microbiology. 1995;141:687-94.

41. Beney L, Marechal P, Gervais P. Coupling effects of osmotic pressure and temperature on the viability of Saccharomyces cerevisiae. Appl Microbiol Biotechnol. 2001;56:513-6.

42. Varsha KK, Priya S, Devendra L, Nampoothiri KM. Control of spoilage fungi by protective lactic acid bacteria displaying probiotic properties. Appl Biochem Biotechnol. 2014;172:340213.

43. Bujňák L, Maskalová I, Vajda V. Determination of buffering capacity of selected fermented feedstuffs and the effect of dietary acid-base status on ruminal fluid $\mathrm{pH}$. Acta Vet Brno. 2011;80:269-73.

44. Cao Y, Takahashi T, Horiguchi KI, Yoshida N. Effect of adding lactic acid bacteria and molasses on fermentation quality and in vitro ruminal digestion of total mixed ration silage prepared with whole crop rice. Grassland Sci. 2010;56:19-25.

45. Bach A, Iglesias C, Devant M. Daily rumen $\mathrm{pH}$ pattern of loose-housed dairy cattle as affected by feeding pattern and live yeast supplementation. Anim Feed Sci Technol. 2007;136:146-53.

46. Lyberg K, Olstorpe M, Passoth V, Schnürer J, Lindberg JE. Biochemical and microbiological properties of a cereal mix fermented with whey, wet wheat distillers' grain or water at different temperatures. Anim Feed Sci Technol. 2008;144:137-48.

47. Yang SY, Ji KS, Baik YH, Kwak WS, McCaskey TA. Lactic acid fermentation of food waste for swine feed. Bioresour Technol. 2006;97:1858-64.

48. Suiryanrayna MVAN, Ramana JV. A review of the effects of dietary organic acids fed to swine. J Anim Sci Biotechnol. 2015;6:45.

49. Refstie S, Sahlström S, Bråthen E, Baeverford G, Krogedal P. Lactic acid fermentation eliminates indigestible carbohydrates and antinutritional factors in soybean meal for Atlantic salmon (Salmo salar). Aquacult. 2005;246:331-45.

50. Allen MS. Relationship between fermentation acid production in the rumen and the requirement for physically effective fiber. J Dairy Sci. 1997;80:1447-62. 